\title{
Water temperature in investigations of Polish lakes
}

\author{
Rajmund Skowron
}

Faculty of Earth Sciences, Nicolaus Copernicus University in Toruń, Lwowska 1, 87-100 Toruń, Poland, e-mail: rskowron@umk.pl

\begin{abstract}
Scientists became professionally interested in Polish lakes in the early 1850s. They focused predominantly upon the measurements of depth, observations of water stages, optical properties, and water temperature. The first systematic observations of surface water temperature were carried out in 1956. At present these measurements are conducted in 29 lakes. Investigations of the vertical distribution of water temperature were initiated in the interwar period and they contributed to a better recognition of the processes and factors conditioning dynamics of water masses. In general, measurements of water temperature have constituted fundamental observations with respect to the studies of yearly and daily courses of the temperature of surface water and the entire water mass, the influence of basin morphometry upon water thermal conditions, heat balance and heat resources, thermal conditions of bottom deposits and thermal classification of the lakes. The introduction of automatic gradient probes gave a new impulse to the investigations of water temperature in the lakes. The foundation of the Polish Limnological Society in 2001 and 18 national and international limnological conferences stimulated integration of the circle of limnologists. Specialist journals (Limnological Review, Studia Limnologica et Telmatologica) have presented around 40 publications with the leading theme of water temperature.
\end{abstract}

Key words: lakes, water temperature, history of investigations, Poland

\section{Introduction}

Modern limnology treats the lake as a functional natural object which comprises a series of interacting physical, chemical and biological systems. The existence and functioning of water bodies is possible owing to continuous links with alimentation supply (Okulanis 1977). Not without reason, many investigations carried out in Polish lakes and their catchment areas in the last 20 years have been of a complementary character. The area of the lake catchment has become a very vulnerable element of the entire system, often referred to as a natural territorial system (Lange 1985b). One of the essential elements of this system is water temperature which is the effect of the inflow and outflow of the energy stream and the processes and mechanisms which occur in the closed system of the lake basin. Apart from the fluctuations in water stages, ice phenomena and water temperature are the main abiotic factors shaping the lake ecosystem.

The temperature of lake waters, ice phenomena and fluctuations in water stages are essential abiotic factors which decide on the functioning and dynamics of the lake ecosystem. The temperature of lake waters is one of the main features which determines water properties in geographic investigations. Lakes should be treated as specific elements of the flow and transformation of energy in inland ecosystems (Starmach et al. 1976; Lange 1985b, 1993; Lampert and Sommer 1996), in which the following can be distinguished: an active layer, a light zone, a zone of water circulation, a zone of water stagnation, and a zone of matter sedimentation (Lange 1985a). Water temperature is one of such links, influencing most processes that take place in the lake ecosystem. According to Welch (1948), it is temperature, unlike any other individual factor, that strongly determines direct and indirect consequences for the lake (after Turczyński 1995).

Lake water temperature has a decisive influence on the pace of matter transformation and also shapes settlement conditioning. It is necessary to pay close attention to the water temperature of lakes when significant climate changes can be observed (global warming), which cause positive trends in the yearly temperature of the surface water in the lakes, and negative trends of heat resources and mean water temperature during the summer (Skowron 2007b, 2011a). The first stationary observations in this range are of particular interest. 


\section{History of the examinations of water temperature in the Polish lakes}

Scientific interest in Polish lakes dates from the early 1850s. Polish and foreign (mainly German) researchers studied the lakes located within the territory of contemporary Poland. Their investigations mainly involved measurements of depth, observations of water stages, optical properties and water thermal conditions (Lencewicz 1925; Szaflarski 1932; Bajerlein 1950). The researchers were particularly interested in the Tatra Mountains and Suwałki region lakes (Birkenmajer 1901; Lencewicz 1925; Szaflarski 1950; Lange and Faraś-Ostrowska 1993; Choiński 2007).

\section{First examinations of lake water temperature}

The measurements of the water temperature of Polish lakes began in the latter half of the nineteenth century, though the very first measurement was taken by S. Staszic in 1804 in Lake Czarny Staw below Mount Rysy (Choiński 2014). The first observations focused mainly on the Tatra lakes, and lakes located in Greater Poland, Pomerania and Masuria (Choiński 2007). E. Dziewulski and L. Świerz should be mentioned among many researchers (Lencewicz 1925; Szaflarski 1932). They studied lake morphometry and water thermal conditions (Birkenmayer 1901; Bojanowicz 1970; Choiński 2007). The studies conducted by Szaflarski (1932) in the early twentieth century also concentrated on water temperature and winter thermal conditions (Szaflarski 1950; Bojanowicz 1970). L. Cohn, a German observer, attempted to determine thermal relations in the lakes and the manner of water mixing in Lake Niegocin in 1901 (Kondracki 1952). Due to short, sometimes individual and non-synchronous observation series, most works do not, however, constitute interesting material.

\section{Examinations of lake water temperature during the interwar period}

After Poland had regained independence the Hydrographic Office (Hydrographic Institute from 1934) undertook the investigations of the lakes. The research output of Polish geographerswas widely discussed in the study by Lencewicz (1925). The author lists the researchers of the Tatra lakes (Dziewulski, Birkenmajer, Sawicki and Lityński), Greater Poland lakes (Schütze, Sperczyński), Pomeranian lakes (Seligo, Halbfass), Dobrzyń region lakes (Dziewulski, Nechay), Kuyavian lakes (Sawicki), Gostyń region lakes (Lencewicz, Staff), Augustów region lakes (Kulawieć, Lityński, Dembowski, Stenz, Koźmiński and Wiszniewski), ŁęcznaWłodawa lakes (Lityński, Dziewulski, Sawicki), Vilnius region lakes (Staff, Dybowski), and Polesye lakes (Tutkowski, Swidzińska). The summaries of the results and studies of water temperature were reflected in the works of Szaflarski (1932,1950) and Swidzińska (1939). The works of Bajerlein (1926) and Szaflarski (1932) are particularly interesting as the authors analyse the course of water temperature in Lake Wielkie in the Greater Poland Lakeland and more than a dozen Tatra lakes. The research concerning winter thermal stratification of water in the largest Tatra lakes is outstanding (Szaflarski 1950). Unfortunately, the results of the measurements were lost during the war. Only individual studies survived (Birkenmajer 1901; Lencewicz 1925; Bajerlein 1926; Szaflarski 1932).

Examinations of lake water temperature in the latter half of the twentieth century

The depth probes and preparation of bathymetric plans for well over two thousand lakes by the Institute of Inland Fisheries in Olsztyn in the 1950s and 60 s opened up an entirely new stage in lake research. A network of measurement stations was established by the Institute of Meteorology and Water Management in the 1950s to record water stages, surface water temperature, ice phenomena and evaporation in some cases. Undoubtedly, research programmes to monitor lake purity carried out by several institutions were of significant importance. These included university centres and research stations, among others in Mikołajki, in Charzykowy, in Kobylec near Wągrowiec, in Borucino on Lake Raduńskie Górne, in Siemionki on Lake Gopło, in Gosławice on Lake Pątnowskie and in Radzyń on Lake Sławskie (Bojanowicz 1970; Nawrocka 1986; Pasławski 1993; Choiński 2007b, 2010; Skowron 2011a). The Voivodship Inspectorate of Environmental Protection (previously the Environmental Research and Control Centres) has contributed largely to recognising the condition of the natural environment. They have monitored and provided information on the environment for the entire country.

The first systematic observations of surface water temperature began in 1956 in two lakes: Gopło and Studzieniczne. However, 1960 is the true beginning of these observations as over 20 lakes representing the most important lakeland regions were continuosely surveyed.

In the period between 1961 and 1970 there were 10 posts measuring the surface water temperature (SWT) in the following lakes of the Pomeranian Lakeland: Jamno, Gardno, Łebsko, Żarnowieckie, Myśliborskie, Lubie, Raduń, Charzykowskie, Raduńskie Górne and Sępoleńskie. A group of 11 lakes were measured in the Masurian Lakeland: Chełmżyńskie, Jeziorak, Druzno, Łańskie, Nidzkie, Mikołajskie, Jagodne, Selmęt Wielki, Studzieniczne, Białe and Hańcza, while in the Greater Poland-Kuyavian Lakeland only three posts 
were active in the lakes: Sławskie, Góreckie and Gopło. However, observations of lakes Myśliborskie, Raduń, Chełmżyńskie, Druzno, Łańskie and Jagodne lasted for only a few years (Bojanowicz 1970).

In the years 1971-1980 the network of measurement posts developed significantly. Among 120 measurement and observation stations located in the lakes, which conducted systematic observations of water levels and ice phenomena, 35 also recorded surface water temperature (SWT). During this period water temperature measurements were initiated in the lakes: Trzcinno, Jasień, Mikorzyńskie, Ślesińskie and Pątnowskie, but 2-3 years later the measurements were stopped.

In the years 1981-1990 the number of investigated lakes increased to 36 , although lakes with a relatively long observation series were not subject to further studies (Zbąszyńskie, Miedwie, Góreckie and Białe Włodawskie). A number of SWT measurement posts were closed between 1991-1995. In that period measurements in lakes: Narie, Dargin and Wielimie were discontinued. Hence, only two lakes: Studzieniczne and Gopło have an unbroken 60-year long observation series (1956-2015) and the lakes: Sławskie, Charzykowskie, Raduńskie Górne, Gardno, Łebsko, Jeziorak, Nidzkie, Mikołajskie and Hańcza have a 55-year long measurement series. Lakes: Gopło, Nakielno, Lubie, Drawsko, and Jamno have discontinuities, sometimes for more than two or three weeks, or even as much as for a year, which diminishes the worth of this indisputably valuable material (Dynus 1974; Skowron 1997a).

In 2014 the observations of SWT in five other lakes (Morzycko, Sławianowskie, Ińsko, Niesłysz and Komorze) were commenced. Currently the surface water temperature is measured in 35 lakes. Moreover, the measurements of surface water temperature and evaporation are carried out at four anchored evaporation stands in the lakes: Sławskie, Łebsko, Raduńskie Górne and Rajgrodzkie. In 1981 measurements at the "Potrzymiech" evapourmetric stand in Lake Gopło were discontinued after 19 years of observations.

The measurements of surface water temperature (SWT) in Polish lakes are carried out in the litoral zone once a day at 7:00 (6:00 GMT) at a depth of $0.4 \mathrm{~m}$. The results of these measurements are representative of the entire lake (Gieysztor 1960; Skowron 1997a, 2011a; Górniak 1999).

The analysis of the daily values of surface water temperature in the multi-year period show its varied regional course (Fig. 1). The highest values of the mean yearly surface water temperature (the limnological isotherm above $10^{\circ} \mathrm{C}$ ) are recorded in the central and southern part of the Dobrzyń and Kuyavian Lakelands, and the eastern part of the Greater Poland Lakeland (Kowalska 1972; Apenit 1982). On the other hand, the lowest mean yearly SWT values (the limnological isotherm below $9^{\circ} \mathrm{C}$ ) are recorded in the northern part of the East-Suwałki Lakeland, the Kashubian Lakeland, and the Słowińskie Coastland. The remaining areas are located within the $9-10^{\circ} \mathrm{C}$ limnological isotherms (Skowron 2011a).

In the course of mean monthly surface water temperature the highest values were recorded in July 1994 when the mean monthly water temperature exceeded $24^{\circ} \mathrm{C}$ (Jeziorak $-25.2^{\circ} \mathrm{C}$, Powidzkie $-24.8^{\circ} \mathrm{C}$, Gopło $24.3^{\circ} \mathrm{C}$ and Sławskie $-24.1^{\circ} \mathrm{C}$ ). The highest values of surface water temperature in Polish lakes were most frequently observed at the turn of July and August (Skowron 2009c). Exceptionally high temperatures of $30.2^{\circ} \mathrm{C}$ were recorded on 7th July 1991 in Lake Nakielno and $29.2^{\circ} \mathrm{C}$ on 16 th August 1994 in Lake Jeziorak (Skowron 2009c, 2011a).

Changes in water temperature observed over a longer period of time are particularly interesting. The analysis of long-term changes in the temperature of surface water in different lakes in the northern hemisphere shows a noticeable increase in the latter half of the twentieth century (Skowron 2009d). The conducted calculations indicate that in the years 1971-2010 the mean yearly values of surface water temperature in Polish lakes show a positive trend at the level of $0.02-0.05^{\circ} \mathrm{C} \mathrm{yr}^{-1}$ in all the lakes, except for Morskie Oko $\left(0.08^{\circ} \mathrm{C} \mathrm{yr}^{-1}\right)$ (Skowron 1997b; Dąbrowski et al. 2006; Sobolewski et al. 2014).

Considerable differences are also observed in the spatial distribution of surface water temperature throughout Poland (Kowalska 1972; Skowron 1997a, 1999a). The temperature of water within the range of $2-4^{\circ} \mathrm{C}$ in the spring can be recorded 14 days earlier in the lakes located in the Greater Poland Lakeland than in those located in the Pomeranian Lakeland, and 19 days earlier than in the lakes of the Masurian Lakeland. However, in the summer half-year a reverse situation can be observed, although these differences are noticeably smaller (Skowron 2011b).

The multi-year measurements make it possible to distinguish thermal seasons in the annual thermal cycle (Kowalska 1972; Grześ 1974; Jędrasik 1985; Janiec and Turczyński 1988; Skowron 1999a, 2007a). These seasons criteria are most frequently related to: the formation and disappearance of the ice cover, surface water temperature remaining permanently over the values of 4 and $15^{\circ} \mathrm{C}$ both in the spring and autumn. The dates with minimum and maximum temperatures of water are also taken into consideration. Such a division of the year into thermal seasons makes it easy to understand most processes which determine the thermal regime of the lakes (Skowron 2001, 2011a; Skowron and Piasecki 2014).

Investigations into the vertical distribution of water temperature also have their own history. They began a 

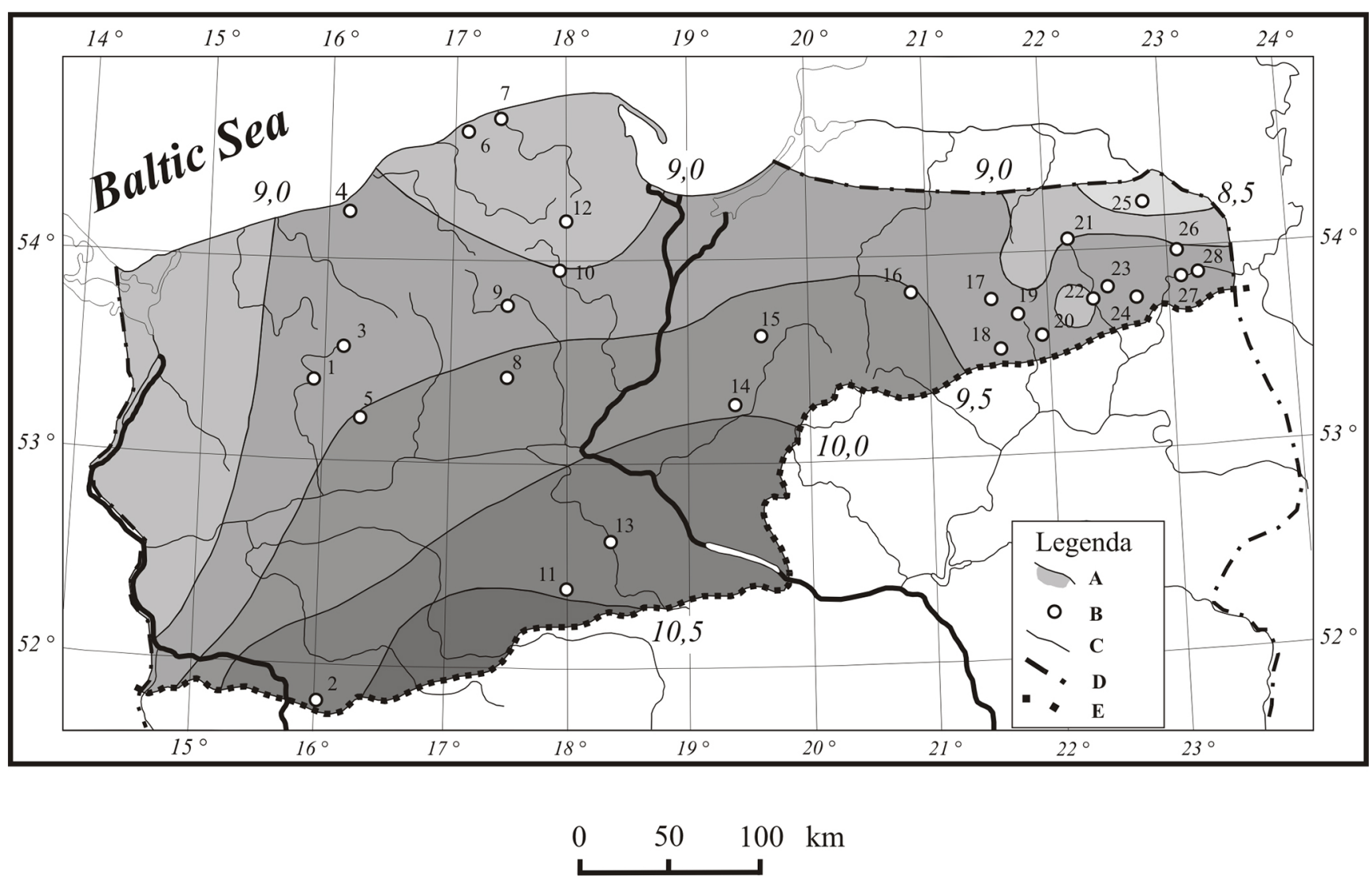

Fig. 1. Course of annual limnoisotherms (XI-X) and the distribution of the lakes included in the measurements of surface water temperature in the period 1971-2005 (according to Skowron 1997a - partially changed): A - annual limnological isotherms, B - lakes (1 - Lubie, 2 Sławskie, 3 - Drawsko, 4 - Jamno, 5 - Nakielno, 6 - Gardno, 7 - Łebsko, 8 - Sępoleńskie, 9 - Charzykowskie, 10 - Wdzydze Południowe, 11 - Powidzkie, 12 - Raduńskie Górne, 13 - Gopło, 14 - Bachotek, 15 - Jeziorak, 16 - Dadaj, 17 - Mikołajskie, 18 - Nidzkie, 19 - Śniardwy, 20 - Roś, 21 - Litygajno, 22 - Ełckie, 23 - Selmęt Wielki, 24 - Rajgrodzkie, 25 - Hańcza, 26 - Wigry, 27 - Białe Augustowskie, 28 - Studzieniczne), C - rivers, D - border of Poland, E - the maximum extent of the Vistulian Glaciation

new stage of limnological research, and contributed to a better recognition of the processes and factors shaping water mass dynamics. The developments in technologies and measurement devices have been of great importance as well.

The first observations of the vertical structure of water temperature in Polish lakes were conducted as early as the interwar period. The examinations of temperature and absorption of solar radiation conducted in the Wigry region lakes in the years 1920-1939 show interesting findings on the issues of thermal stratification (Koźmiński and Wiszniewski 1935; Świdzińska 1939).

These initial measurements were carried out by means of reversing thermometers and mercury thermometers placed in the water samplers (Kondracki 1952). A new period in the investigations of water thermal conditions began in the 1960s owing to the increasing demand for lake management and exploitation as well as the construction of electronic thermometers with a cable, which made it possible to measure water temperature at any depth (Mikulski and Okulanis
1974). The first measurements of temperature in the vertical refer to observations carried out in the Masurian lakes (Kondracki 1952). Measurements in the lakes: Niegocin, Mikołajskie, Śniardwy and Tałtowisko (Kondracki 1952; Chojnowski 1967) were important to explain essential processes undergoing in the lakes The term thermal stratification was used for the first time in Polish literature. Similar investigations were carried out in Dargin and Mikołajskie lakes in the summer period by Paschalski $(1959,1960)$.

At the same time (the summer of 1951) examinations of water temperature in six lakes of the ŁęcznaWłodawa Lakeland began with the use of reversing thermometers (Wilgat 1953). In the years 1966-1969 measurements in 53 lakes of this region were performed twice, whereas in the years 1970-1976 there were systematic observations in the following lakes: Piaseczno, Bikcze and Brzeziczno (Radwan et al. 1973; Radwan and Kowalczyk 1979). Observations of the course and dynamics of water temperature in the annual cycle 
were a continuation of these investigations (Janiec and Turczyński 1988; Turczyński 1995, 1998).

Systematic measurements of vertical distribution of water temperature in the Raduńskie lakes began with the help of the Limnological Station in Borucino in the 1960s (Pasławski 1993). Mikulski and Okulanis (1974) presented the results of the 10-year long examinations on Lake Raduńskie Górne. The modernisation of measurement equipment allowed for more detailed and precise examination. Above all, the number of measurements increased. These investigations were conducted by various institutions, such as university geographical, hydrobiological centres and fisheries centres (Pasławski 1993).

These pioneering observations revealed that the autumn homothermy occurred in October, whereas the spring homothermy took place after the disappearance of the ice cover. The assumption about the dependency between the size of the lake and the position of its thermocline is of great value (Patalas 1960a, b). In the summer the differences in the temperature of the surface water layer (of 1-m thickness) between various parts of the lake may even reach several degrees, and the mean day values amounted to $0.5^{\circ} \mathrm{C}$. The diversity in the temperature values between the littoral zone and the lake's open parts has been considered by Gieysztor (1960) and Starmach et al. (1976). The expeditionary investigations carried out in lakes of different shapes and varied elements of the lake basin (Gopło, Bachotek, Jeziorak, Hańcza, Drawskie, Morzycko, Wigry, Wiecanowskie) showed the greatest differences between the littoral and profundal zones occurred during the spring warming of lake water (Skowron 1997a). In some weather conditions the maximum differences in the temperature of surface water even exceeded $8^{\circ} \mathrm{C}$, yet they most frequently oscillated between $1.5-2.5^{\circ} \mathrm{C}$, as proven by a thermal photograph of Lake Żarnowieckie taken with an infrared camera in 1978 (Onoszko 1979).

The significant majority of observations of water thermal conditions are connected to expeditionary measurements conducted in individual or in groups of several lakes, most frequently during summer periods. The results of such measurements have been presented for the following water bodies: Lake Jeziorak (Bojanowicz 1971; Churski 1988), Lake Gopło (Grześ 1974, 1976; Skowron 1980, 1982, 1990), Lake Komorze (Czerwińska 1975), Lake Zamkowisko Duże (Okrągła 1977), Lake Hańcza (Skowron 1999b), Lake Bachotek (Skowron 2000), Lake Kortowskie (Mientki and Wiśniewski 2001), Lake Zamkowe (Choiński and Kanikowski 2004), Lake Pluszne (Grochowska and Tandyrak 2006), Lake Pątnowskie (Pasławski 1993), lakes of the Konin region (Chojnowski 1972), lakes of the Sława Lakeland (Koczorowska 1974; Rösler 1986, 2001), lakes of the Kashubian Lakeland (Jędrasik and Lange 1972; Mikulski and Okulanis 1974; Jędrasik 1975; Lange 1975, 1978, 1985a, 1986; Okulanis 1981; Lange and Maślanka 1997; Trojanowski and Bruski 2002; Borowiak 2003; Trojanowski and Parzych 2004; Maślanka et al. 2005; Nowiński et al. 2005, Maślanka and Nowiński 2006, Maślanka and Barańczuk 2007, Borowiak et al. 2008), lakes of the West-Pomeranian Lakeland (Nguyen Van 1972; Kubiak 2003; Kubiak and Tórz 2005, 2006; Kubiak et al. 2007), lakes of the Masurian Lakeland (Olszewski et al. 1978), lakes of the Łęczna-Włodawa Lakeland (Janiec and Turczyński 1988; Turczyński 1995), lakes of the Gniezno and Kuyavian Lakelands (Skowron 1980, 1982, 1990), lakes of the Dobrzyń Lakeland (Marszelewski 2001), lakes of the Ełk Lakeland (Jańczak and Maślanka 2006), lakes in the basin of the River Łyna (Maślanka et al 1996), the deepest lakes in Poland (Skowron 2009b), and the lakes located in the Tuchola Forest National Park (Choiński et al. 2012; Błoniarz et al. 2016). In total, about 105 lakes were considered in such investigations.

It was established that in summer the mean temperature of near-the-bottom waters and the mean gradient of the temperature in the metalimnion were strongly correlated with the lakes' depth indicators (with the maximum, mean and relative depths). A similar trend and high dependency was observed with respect to the density index (Kubiak 2003) and the heat content index in the lake (Skowron 2011a).

The measurements of water temperature in the mountain lakes were also of an expeditionary nature. They started 130 years ago, encompassing only the Tatra lakes. Stationary measurements concerning the temperature of surface water began in Lake Morskie Oko in 1967 (Choiński 2014). On the other hand, measurements conducted in the thermal vertical profiles were unsystematic and had only a short series (Lange et al. 1976, 2000; Łajczak 1982; Borowiak 2002; Choiński et al. 2013,2015). Observations on water temperature also included the Great and Small Lake in the Karkonosze Mountains. Parallel bathymetric measurements were conducted, and the results have been presented in the work of Komar (1978). Measurements of the vertical course of water temperature make up a separate chapter from the utilization of the anchored thermal probe (Choiński and Łyczkowska 2008; Łyczkowska 2009).

Measurements of temperature conducted during ice cover are also interesting (Skowron 2006, 2008a, b). After the formation of ice cover katothermal stratification develops in most cases. The lowest temperature can be recorded directly under the ice cover, then from a depth of 3-4 $\mathrm{m}$ it gradually increases to $3.6-4.0^{\circ} \mathrm{C}$ at the bottom of the deepest lakes. Atypical stratification (anomaly) occurs temporarily at the end of the icing 
period during certain weather conditions and does not have spatial continuity in the lake (Jędrasik 1975).

The course of thermal cycles is one of the criteria thatshow thermal differences (Jędrasik 1985; Skowron 2007a, b, c, 2011b, 2012). Thermal cycles determine various mictic types of lakes. The spring cycle begins earliest in the tachymictic lakes of the Greater Poland Lakeland, and latest in the bradymictic lakes in the Suwałki region. Thermal diversity of the lakes determined by mictic conditions of water masses attracted the attention of Olszewski (1959), Patalas (1960b), Paschalski $(1959,1960)$, and Okulanis $(1976,1981)$. The investigations based upon the thermal balance method carried out in 20 lakes of the Kashubian Lakeland show that the general heat content in the lakes reveals significant relations with climatic conditions and morphometric and hydrological properties (Lange 1978). The equation of the thermal balance comprised its four components: radiative balance of the water surface, heat loss to evaporation, changes in heat content in the lake and balance difference. The accumulation of heat remained in Lake Raduńskie Górne from February to August, whereas its emission occurred in January and from September to December. As for the remaining lakes the biggest differences were recorded when the lake moved from the emission phase to the accumulation phase. The thermal regime in the lakes of the Upper Radunia River is also determined by the elements of water balance and their water mixing (Okulanis 1977).

The course of water temperature in very shallow water bodies is also interesting. They reveal a distinctly polymictic character and virtual distribution of temperature both in a daily and yearly distribution, similar to the course of air temperature (Drwal and Lange 1985).

Shallow water bodies present high day and yearly amplitudes and minimum diversity of water temperature in their entire mass . Noticeable thermal stratification develops in summer when the weather is sunny. The temperature in the surface layer exceeds $28-30^{\circ} \mathrm{C}$, although such conditions are of very short duration. Szumiec (1984) concludes that in the case of shallow bodies of a pondlike nature the surface temperature $(0.5 \mathrm{~m})$ often exceeds $28-30^{\circ} \mathrm{C}$, and the number of days with a temperature above $14^{\circ} \mathrm{C}$ amounts to 138 .

The Voivodship Inspectorates of Environmental Protection in Szczecin, Zielona Góra, Poznań, Gdańsk, Bydgoszcz, Olsztyn and Białystok also provide abundant observation materials concerning the vertical measurements of water temperature. The measurements of thermal and oxygen conditions refer mostly to lakes which have never been studied by any institutions. The results were partially presented in a study concerning the thermal regimes of Polish lakes (Skow- ron 2011a; Sobolewski et al. 2014). They complement gaps in the expeditionary research and make up a material comprising over 1000 lakes.

The investigations of the daily course of water temperature in the lakes were performed both in the surface layer and along the vertical profile. The lakes subjected to such measurements are located in various regions of Poland (Skowron 1999a, 1999c, 2000, 2011a; Sobolewski et al. 2014). The measurements of the daily course also referred to the Tatra lakes (Lange et al. 1976; Łajczak 1982; Borowiak 2002). The results of the observations, particularly in the lakes of the Polish Lowland indicated that the mean daily temperature of the surface water was recorded twice a day. It occurred between 8:00-11:00 (7:00-10:00 GMT) for the first time, and between 20:00-21:00 (19:00-21:00 GMT) for the second time. The highest values were recorded between 15:00 (14:00 GMT) and 18:00 (17:00 GMT), whereas the lowest temperature values can usually be recorded between 5:00-7:00 (4:00-6:00 GMT). Changes in the daily course of water temperature are clearly noticeable down to a depth of 2.5-3.5 m, although they are perceivable down to 5.5-7.0 m (Skowron 2011a).

Bottom deposits constitute an integral part of the lake ecosystem. They expose the genesis of the lake basin. Researchers have been interested in the measurements of the bottom deposits since the start of limnological studies. Bajerlein (1950) notes that the measurements of temperature were carried out with the use of Six's thermometer which comprised several rods with a mercury thermometer at one end of it. The thermal processes occurring at the limits of the water mass and the lake bottom are important, and therefore, should be considered when analysing the heat balance of the lakes (Bajerlein 1926).

The examinations conducted in Lake Gopło and several smaller neighbouring lakes by Grześ $(1973,1978)$ prove that the measurements of deposits at the depth of $0.2-0.3 \mathrm{~m}$ are of great scientific value and should be carried out alongside temperature measurements of near-the bottom waters. Temperature measurements of bottom deposits at greater depths should be conducted every $0.5 \mathrm{~m}$. Beyond any doubt, during the winter months shallow lakes are found to have a higher temperature of surface deposits $(0.2 \mathrm{~m})$ than water mass temperature, which confirms the existence of a period of heat emission by deposits. During the summer the situation is the reverse. Measurements in the lakes: Gościąż and Mielec provide a good illustration (Grześ and Sobota 1996). Measurements taken in the deposits $(6 \mathrm{~m})$ at greater depths show that the heating of deeper layers occurs later than in the surface layers. During the year the biggest changes in the temperature of the deposits take place in the layer at the depth of $3 \mathrm{~m}$, which is referred 
to as the thermally active layer. The depth at which the temperature amplitude of the bottom deposits during the year does not change is called the suppressing depth (Grześ 1978). On the basis of the temperature measurements of the bottom deposits it is possible to determine to a good approximation the mean temperature of the water mass in the lake, and establish precisely the mictic type of the lake. Therefore, the temperature of the bottom deposits may be an objective indicator of the thermal classification of the lakes.

The thermal classification of lakes in Polish literature was presented by Gołębiewski and Lange (1975), Bernatowicz (1981), Jędrasik 1985, Skowron (2009a, 2010, 2011a), and Sobolewski et al. (2014). Most of the above authors believe that due to the location of Polish lakes and the smaller morphometric parameters of their lake basins, the classifications by Chomskis (1969) and Kitaev (1978) seem the most representative typologies. Unfortunately, the thermal classifications of the lakes presented by Wiszniewski (1954) and Bernatowicz (1981) do not meet the fundamental criteria for objectivity and representativeness, and that is why they were omitted in this study.

In general, depending on the leading factor, three basic groups can be differentiated. The first group consists of the classifications based on physical and geographical zonation; the second type of lake classifications refers to the character of water mass mixing and mictic conditions of the water bodies, whereas, the third group accounts for the properties of the water thermal structure of varied detailing (Sobolewski et al. 2014).

The results of the research conducted in the years 1971-2015 and the extent of knowledge of the particular thermal layers and heat resources during the summer stratification in over 1050 lakes located in the Polish Lowland ultimately helped to modify Kitaev's hydrobiological typology (Kitaev 1978), and adopt the relatively simple rules of the thermal classification of the lakes (Skowron 2011a). The classification is presented in Table 1.

Among the analysed 167 lakes the most common types are epithermal lakes (53) and metaepithermal lakes (47), whereas hypothermal lakes are the lowest in number (4) (Skowron 2011a). This results from the low depth of these water bodies. Typical lakes with epithermal properties are: Kołczewo, Domysławskie, Długie and Mętno, whereas Serwy, Łąkorz, Szelment Mały and Stryjewo are metathermal lakes. Hańcza, Babięty Wielkie, Wukśniki, Ciecz (Trześniowskie) and Śremskie are classified as hypothermal lakes (Sobolewski et al. 2014).

Measurements of water temperature were also carried out by Polish scientists outside Poland. The research conducted in the lakes of the polar zone in the Svalbard Archipelago (the Land of Oscar II) at the end of the
Table 1. Thermal classification of the lakes in the Polish Lowland based upon the percentage share of the thermal layers (after Skowron 2011a)

\begin{tabular}{lcc}
\hline \multirow{2}{*}{ Thermical types } & $\begin{array}{c}\text { Volume of } \\
\text { epilimnion }\end{array}$ & $\begin{array}{c}\text { Volume of meta- } \\
\text { and hypolimnion }\end{array}$ \\
\cline { 2 - 3 } & {$[\%]$} & {$[\%]$} \\
\hline Epithermical $(\mathrm{E})$ & $90-100$ & $0-10$ \\
\hline Metaepithermical $(\mathrm{M} / \mathrm{E})$ & $60-90$ & $10-40$ \\
\hline Metathermical $(\mathrm{M})$ & $45-60$ & $40-55$ \\
\hline Hypometathermical $(\mathrm{H} / \mathrm{M})$ & $25-45$ & $55-75$ \\
\hline Hypothermical $(\mathrm{H})$ & up to 25 & above 75 \\
\hline
\end{tabular}

twentieth century is the most well known. The research focused on genetically young lakes located in the marginal zone of the retreating Aavatsmark glacier which has a limited connection with the sea (they remained under the influence of the floating rhythm). These lakes showed specific thermal stratification (Pietrucien and Skowron 1983; Sobota and Nowak 2011). The course of water temperature explicitly indicated that these were typical meromictic lakes of an ectogenic nature (Skowron 1995).

\section{Contemporary examinations of lake water temperature}

A new impulse in the daily examinations of water temperature, both in the day and yearly courses has resulted from measurements taken with automatic gradient probes (Kanikowski 1997; Choiński and Kanikowski 2004; Glazik et al. 2006). They have made it possible to track changes in the temperature of water at various depths in short periods of time. Despite certain reservations concerning the technical side (Nowak and Grześkowiak 2010), the measurements have revealed a more complex picture of the course of water temperature. The daily measurements of water temperature carried out with high frequency at various depths show that in the summer the daily amplitudes in the surface layer reach up to $2-3^{\circ} \mathrm{C}$, rarely exceeding $4^{\circ} \mathrm{C}$. During intense insolation and windless conditions they may even amount to $5.5^{\circ} \mathrm{C}$, whereas, when it is cloudy and there is considerable undulation the amplitudes are most frequently in the range of $0.8-2.0^{\circ} \mathrm{C}$.

Automatic gradient probes were installed in five lakes: Wielki Staw in the Karkonosze Mountains, Morskie Oko and Czarny Staw below Mount Rysy in the Tatra Mountains, as well as Ostrowickie, Bachotek and Starokiejkuckie lakes in the Polish Lowlands. They registered water temperature in the vertical with very high frequency (Łyczkowska 2009; Glazik et al. 2006). These examinations were performed by the Departments of Hydrology and Water Management of the Institutes of Geography of the Adam Mickiewicz University in Poznan and the Nicolaus Copernicus University in Torun. Unfortunately, these measurements were discontinued due to logistic or technical reasons. Never- 
theless, the results of these observations will help to explain many hardly recognised processes shaping the thermal structure of water in the daily and yearly cycle, and particularly during the formation and disappearance of the ice cover.

\section{Methodology and measuring devices}

Methods of measurement develop within the range of conducted investigations and change with the advancement of measurement technologies (Figs 2-8). The classical division of the measurements of water temperature according to the purpose and methods allows stationary and expeditionary measurements to be distinguished. Therefore, the temperature measuring devices in Poland differ substantially. A mercury thermometer (sampler) is used in stationary measurements conducted by the Institute of Meteorology and Water Management. However, various modern thernistor thermometers, multi-parameter probes and gradient thermal electronic probes are used in expeditionary measurements which involve the vertical distribution of water temperature (Choiński and Kanikowski 2004; Glazik et al. 2006).

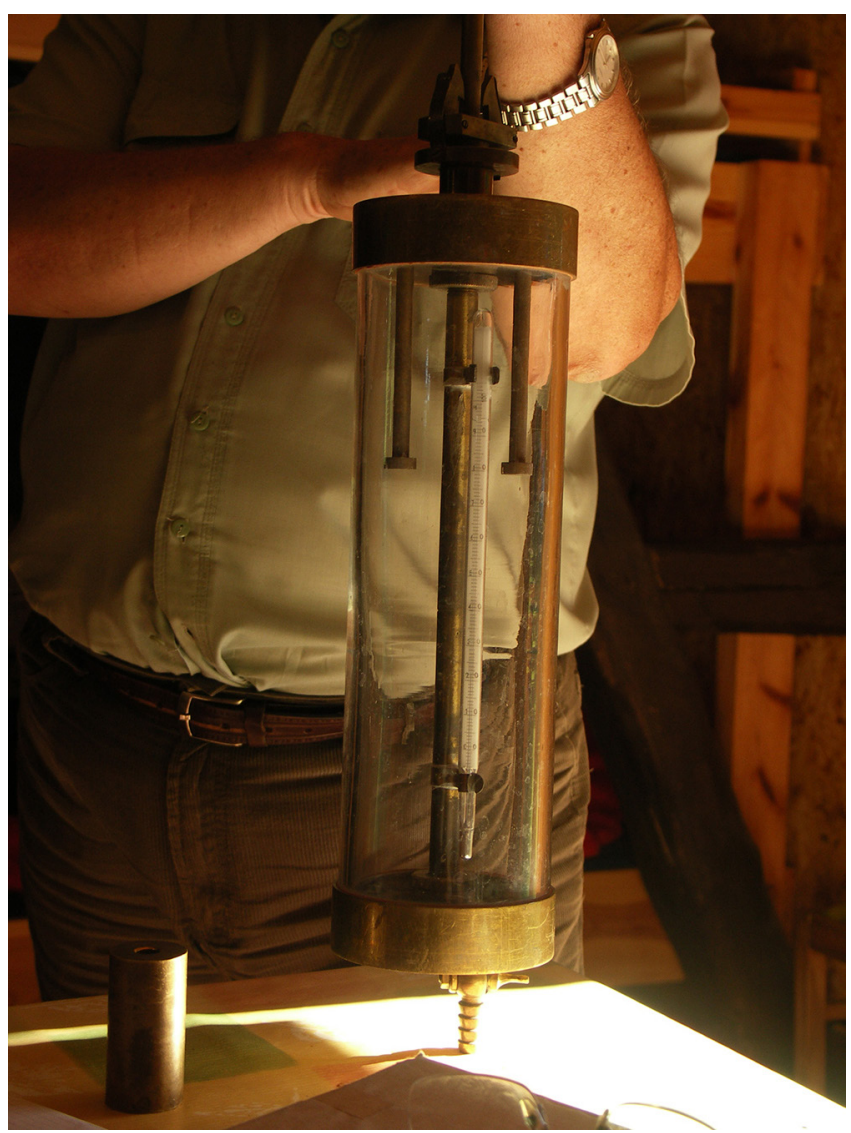

Fig. 2. Ruttner water sampler with a mercury thermometer

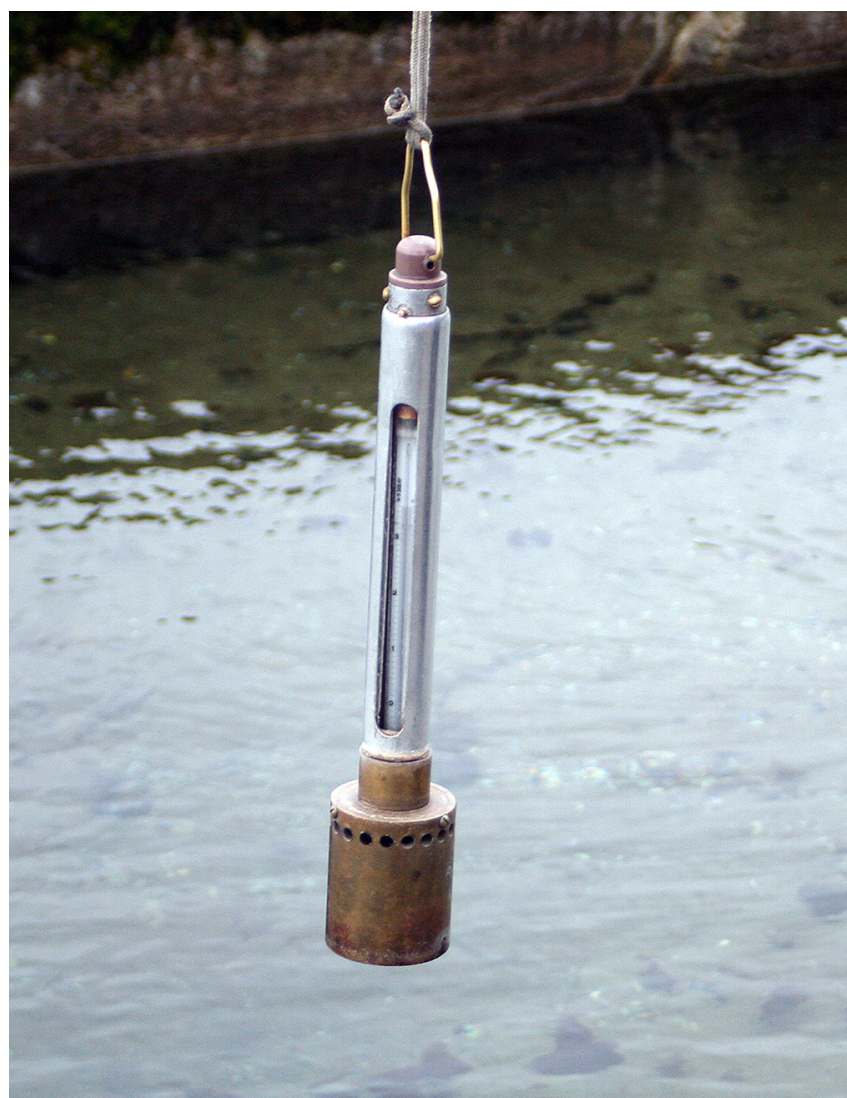

Fig. 3. Sampling thermometer used in stationary measurements of surface water temperature

Stationary measurements made by the Institute of Meteorology and Water Management are carried out with the use of mercury sampling thermometers, most frequently once a day in the littoral zone at 7:00 (6:00 GMT). However, such measurements are hardly representative of the entire lake (Lange and Faraś-Ostrowska 1993).

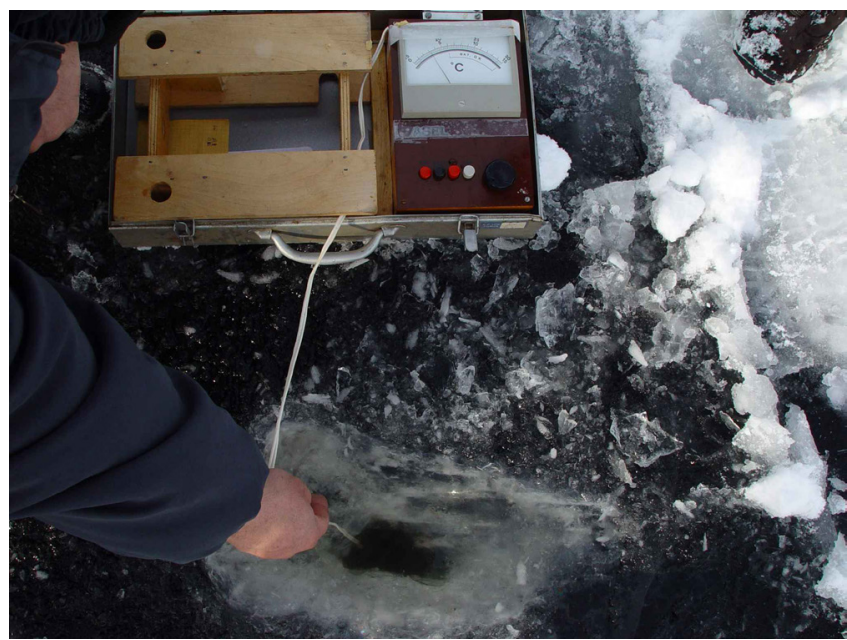

Fig. 4. Electronic thermometer with a cable by Assel 
On the other hand, measurements of water temperature in expeditionary measurements carried out by various institutions (university centres, Voivodeship Inspectorates of Environmental Protection, National Parks, etc.) involve various types of thermistors, more often replaced by multi-parameter probes and registers. In general, the measurements are related to the analysis of water thermal stratification, most frequently performed in the deepest parts of the lake. In order to perceive the vertical diversity of water temperature, such measurements should be conducted at intervals not greater than $1.0 \mathrm{~m}$ (Lange and Faraś-Ostrowska 1993). The examinations showed that in order to properly assess diversity in the vertical thermal structure (VTS - Vertical Thermal Structure) of lakes and accurately determine thermal parameters, including the extent of basic thermal layers,

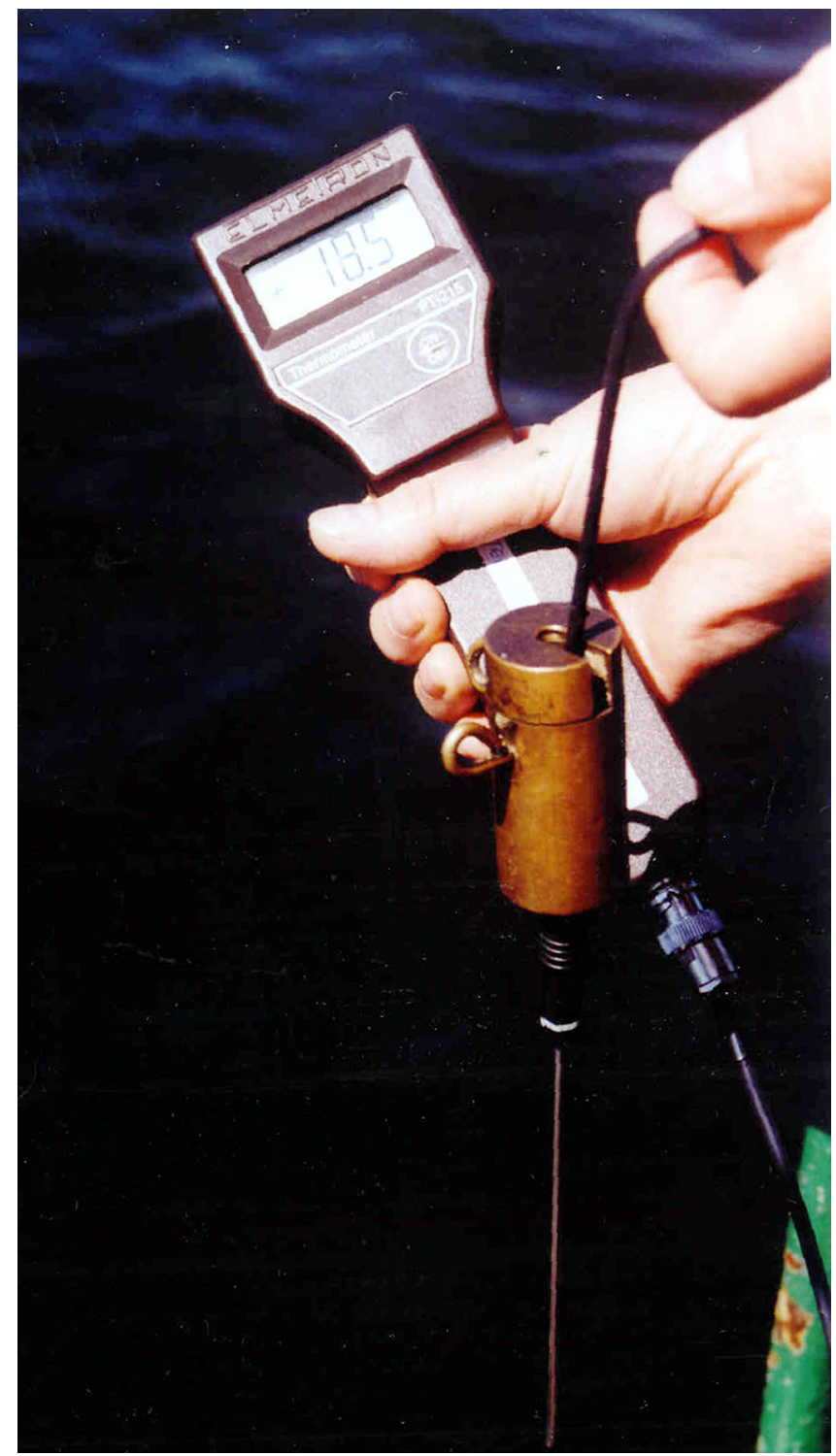

Fig. 5. Thermistor temperature sensor by ELMETRON the measurements of water temperature in the vertical should be carried out every $0.5 \mathrm{~m}$ down to the depth of $15 \mathrm{~m}$ (the maximum extent of epi- and metalimnion), and then every metre down to the depth of $30 \mathrm{~m}$, and every $2 \mathrm{~m}$ deeper (Skowron 2011a).

Rapid advancesin measurement technologies, and particularly the use of electric thermometers allowing for the measurement of water temperature at any depth, have played a significant role in the development of limnology. The invention of the measurement device with the possibility to register many elements, including water temperature has generated a new impulse for interest in the thermal regime of lakes (Choiński and Kanikowski 2004; Glazik et al. 2006; Łyczkowska 2009).

The most popular groups of devices used by Polish researchers in the past and the present to measure water

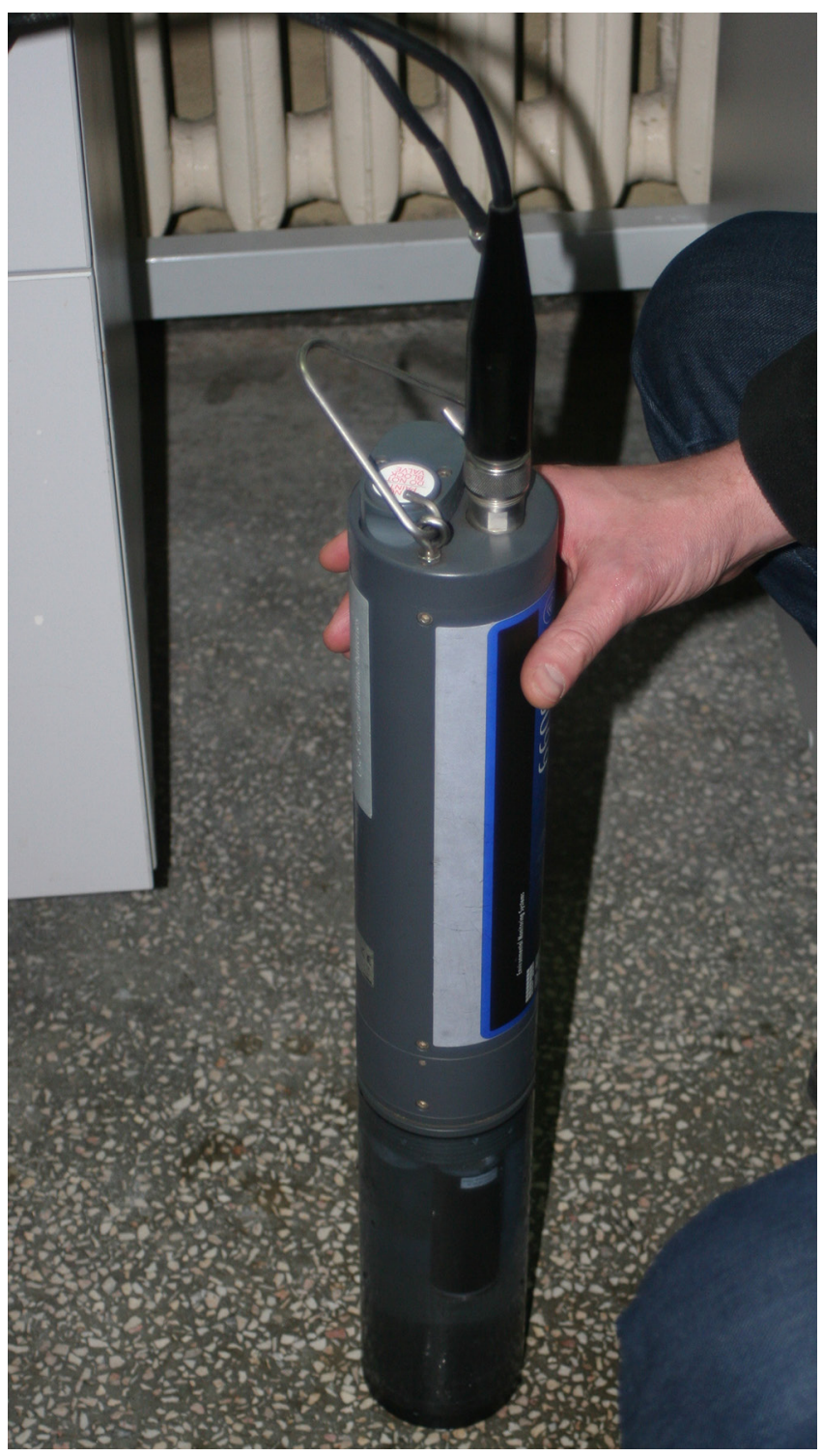

Fig. 6. Multi-parameter water quality probe (600XLM-V2) by ENVAG 


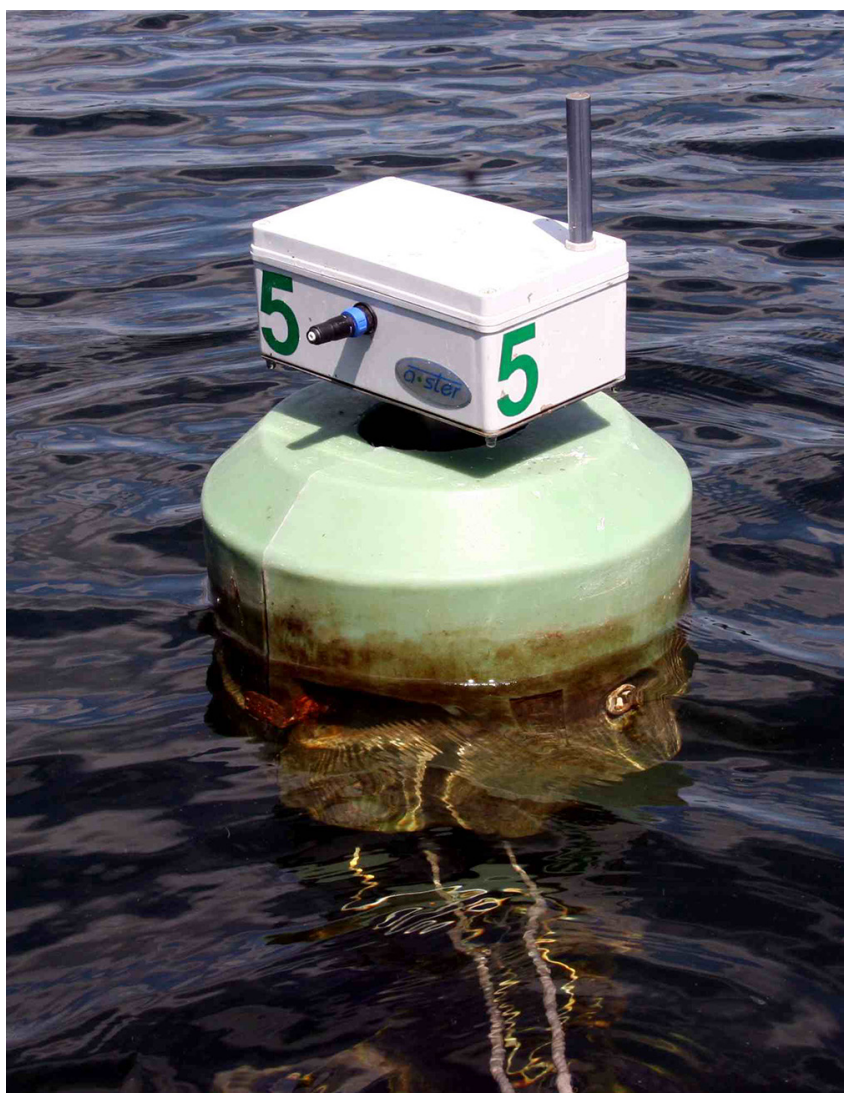

Fig. 7. Thermal gradient probe (RTW8-041) in Lake Ostrowite (Tuchola Forest)

temperature include: reversing mercury thermometers, mercury thermometers placed in samplers, mercury thermometers fitted in cases, electric thermometers with cables (producers: Lis, Assel, Elmetron), gradient thermal probes (RTW8-041), and multi-parameter probes (WTW-OXI-197, 600XLM-V2).

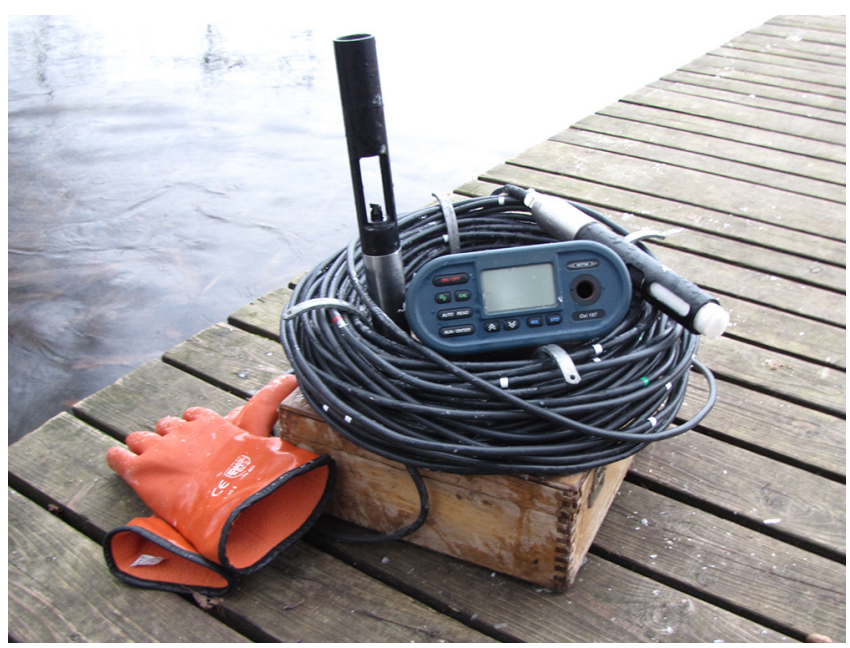

Fig. 8. Oxygen meter (Oxi-197) by WTW

\section{Conclusions}

Lakes have always been attractive research objects, subject to a wide range of observations. Since 1950 nearly 130 articles, where lake water temperature is the leading theme or discussed indirectly, have been published in various Polish and international journals. (Skowron 2011a).

The following research stations established after 1945 have played a major role in limnological research: the Scientific Station of the Institute of Geography of the Polish Academy of Sciences in Mikołajki, the Research Station of the Forestry in Charzykowy, the Limnological Station of Adam Mickiwicz University in Kobylec near Wagrowciec, the Limnological Station of the Higher Educational School in Gdańsk (and since 1970 the University of Gdańsk) in Borucino, the Limnological Station of the National Hydrological and Meteorological Institute in Tęgobórz, the Nicolaus Copernicus University Research Station in Siemionki on Gopło, the Research Station of Heated Waters of the National Hydrological and Meteorological Institute in Gosławice on Lake Pątnowskie, the Nicolaus Copernicus University Limnological Station in Iławie on lake Jeziorak, the Evaporation Research Station of the National Hydrological and Meteorological Institute in in Radzyń on Lake Sławskie and the Nicolaus Copernicus University Limnological Station on Lake Bachotek (Pasławski 1993; Choiński 2007).

The formation of the Polish Limnological Society and organisation of 17 National and International Limnological Conferences in the last 16 years have integrated the circle of limnologists. There are two specialist journals (Limnological Review and Studia Limnologica et Telmatologica) where over $46 \%$ of all articles concern lakes after 1945. Despite such a large body of measurements and the over 135-year long history of observations, there are still many issues which require further comprehensive synthesis (Choiński 2007).

\section{Acknowledgments}

I express our gratitude to Professor Adam Choiński for inspiration and creative discussion regarding the thermals of lake water in Poland.

\section{References}

Apenit E., 1982, Termika wód pojezierzy Niżu Polskiego w latach 1961-1975 (Water temperature of the Polish Lowland lakelands in the years 1961-1975) [Dissertation], UAM, Wydz. Nauk. Geogr. Geol., Poznań, 114 pp (in Polish). 
Bajerlein J., 1926, Kilka spostrzeżeń nad termiką jezior wielkopolskich w porze letniej (A few insights on the thermals of the Greater Poland lakes in summer time), Bad. Geogr. Pol. Pn-Zach. 1: 5-13 (in Polish, French summary).

Bajerlein J., 1950, Kilka uwag dotyczących metodyki badań jeziornych (A few notes on the methodology of lake studies), Prz. Geogr. 22: 17-24 (in Polish).

Bernatowicz S., 1981, Thermal types of lakes in North-Eastern Poland, Ekol. Pol. 29: 585-594.

Birkenmajer L., 1901, O stosunkach temperatury głębokich jezior tatrzańskich w różnych głębokościach i różnych porach roku (On the temperature of the deep Tatra lakes at different depths and different seasons), Rozpr. Wydz. Mat.-Przyr. Akad. Umiej. Krak. 40: 186-411 (in Polish).

Błoniarz W., Choiński A., Ptak M., 2016, Termika wód jeziornych PN „Bory Tucholskie” (Thermal conditions of lake water in the "Bory Tucholskie" NP), [in:] Choiński A., Kochanowska M., Marszelewski W., (eds), Przyroda abiotyczna Parku Narodowego „Bory Tucholskie”(Abiotic nature in the "Bory Tucholskie" National Park), Bogucki Wydaw. Nauk., Poznań: 275-289 (in Polish, English summary).

Bojanowicz M., 1970, Termika wód jeziornych w Polsce i ocena zasobów ciepła w jeziorach (Temperature of lake waters in Poland and assessment of heat resources in lakes) [manuscript], Mat. PIHM 676, Warszawa, 73 pp (in Polish).

Bojanowicz M., 1971, Water temperature and heat resources of the Lake Jeziorak, Zesz. Nauk. UMK Pr. Limnol. 6: 3-13.

Borowiak D., 2002, Struktura termiczna małych zbiorników wodnych w warunkach antropogenicznych zmian właściwości optycznych ich wód (Thermal structure of small lakes under conditions of anthropogenic changes in the optical properties of their water), Zesz. Nauk. AR Krak. Inż. Środ. 23: 11-21 (in Polish, English summary).

Borowiak D., 2003, Influence of horizontal water exchange intensity on epilimnion depth: Case study on Upper Rakuńskie Lake, Limnol. Rev. 3: 17-24.

Borowiak D., Barańczuk J., Nowiński K., 2008, Tranformations of thermal stratification in Upper Raduńskie Lake, [in:] Bajkiewicz-Grabowska E., Borowiak D. (eds), Antropogenic and natural transformations of lakes. Vol. 2, Wydaw. KLUG-PTLim, Gdańsk: 23-26.

Choiński A., 2007, Limnologia fizyczna Polski (Physical Limnology of Poland), Wydaw. Nauk. UAM, Poznań, 547 pp (in Polish).

Choiński A., 2010, Thermal characterisation of Lake Morskie Oko water in 2007 based on measurements by a gradient thermal probe, Limnol. Rev. 10(3-4): 117-126.

Choiński A., 2014, Termika wody (Temperature of water), [in:] Choiński A., Pociask-Karteczka J. (eds) Morskie Oko - przyroda i człowiek (Morskie Oko: nature and a man), Wydaw. TPN, Zakopane: 51-65 (in Polish).

Choiński A., Kanikowski J., 2004, Fluctuations in water temperature of Lake Zamkowe, Limnol. Rev. 4: 33-44.
Choiński A., Łyczkowska G., 2008, Thermal characteristics of waters of Wielki Staw in the Karkonosze Mountains and Morskie Oko in the Tatras, July 2006, Pol. J. Environ. Stud. 17(5): 835-840.

Choiński A., Marszelewski W., Skowron R., 2012, Indywidualizm jezior Parku Narodowego "Bory Tucholskie" na tle jezior $\mathrm{w}$ narodowych parkach polskich (Peculiarity of the lakes in "Bory Tucholskie" National Park against the background of lakes in other national parks of Poland), Stud. Lim. Tel. 6(1): 19-26 (in Polish, English summary).

Choiński A., Pociask-Karteczka J., Ptak M., Strzelczak A., 2014, Zjawiska lodowe (Ice phenomena), [in:] Choiński A., Pociask-Karteczka J. (eds) Morskie Oko - przyroda i człowiek (Morskie Oko: nature and a man), Wydaw. TPN, Zakopane: 66-79 (in Polish).

Choiński A., Ptak M., Strzelczak A., 2015, Changeability of accumulated heat content in Alpine-type lakes, Pol. J. Environ. Stud. 24(6): 2363-2369.

Chojnowski S., 1967, Uwagi o zmianach temperatury wody jeziornej (Remarks on temperature variations in lake water), Wiad. Sł. Hydrol. Meteorol. 3(1): 53-59 (in Polish, English summary).

Chojnowski S., 1972, Wstępna charakterystyka zjawisk termicznych $\mathrm{w}$ jeziorach konińskich (Preliminary characteristic of thermal phenomena in the Konin lakes), Pr. PIHM 107: 99-118 (in Polish, English summary).

Chomskis W., 1969, Dinamika i termika małych ozer (Dynamics and thermals of small lakes), Izdat. Mintis, Vilnius, 204 pp (in Russian).

Churski Z., 1988, Zróżnicowanie przestrzenne i pionowe temperatury wody Jeziora Jeziorak (Spatial differentiation and vertical water temperature in Lake Jeziorak), [in:] Michalczyk Z., Wojciechowski K., Badania hydrograficzne w poznawaniu środowiska (Hydrographic studies in environmental recognition), Wydaw. UMCS, Lublin: 47-57 (in Polish).

Czerwińska D., 1975, Charakterystyka stosunków termicznych i tlenowych Jeziora Komorze, (Characterization of thermal and oxygen properties of Komorze lake), Bad. Fizjogr. Pol. Zach. A 28: 43-74 (in Polish).

Dąbrowski M., Marszelewski W., Skowron R., 2004, The trends and dependencies between air and water temperatures in the lakes located in Northern Poland in the years 1961-2000, Hydrol. Earth Syst. Sc. 8(1): 79-87.

Drwal J., Lange W., 1985, Niektóre limnologiczne odrębności oczek (From studies on the hydrology of hole-lakes), Zesz. Nauk. UGdań. Geogr. 14: 69-83 (in Polish, English summary).

Dynus J., 1974, Metoda określania stosunków termicznych jeziora w przypadku braku systematycznych pomiarów temperatury wody (na przykładzie jeziora Gowidlińskiego) (A method for determining thermic relations in lakes in the case when no systematic water-temperature measurements have been made (on the basis of Lake Gowidlińskie as an example), Zesz. Nauk. UGdań. Geogr. 4: 153-166 (in Polish, English summary). 
Gieysztor M., 1960, On the thermal conditions of the littoral zone of lakes, Pol. Arch. Hydrobiol. 7: 171-193.

Glazik R., Marszelewski W. Skowron R., 2006, Selected problems of registration of vertical distribution of water temperatures in lakes, Limnol. Rev. 6: 103-110.

Gołębiewski R., Lange W., 1975, Stosowalność niektórych typologii limnologicznych na przykładzie jezior Pojezierza Kaszubskiego (Applicability of some limnological typologies as exemplified by the lakes of the Cassubian Lake District), Zesz. Nauk. UGdań. Geogr. 5: 25-56 (in Polish, English summary).

Górniak A., 1999, Dynamika poziomu wód, temperatury i zjawisk lodowych jeziora Wigry (Dynamics of water level, temperature and ice phenomena in Lake Wigry), [in:] Zdanowski B., Kamiński M., Martyniak A. (eds), Funkcjonowanie i ochrona ekosystemów na obszarach chronionych (Functioning and protection of ecosystems in protected areas), Wydaw. IRŚ, Olsztyn: 129-140 (in Polish).

Grochowska J., Tandyrak R., 2006, Temperature and dissolved oxygen profiles in Lake Pluszne, Limnol. Rev. 6: 111-116.

Grześ M., 1973, Metodyka i wstępne wyniki badań nad termiką osadów dennych jeziora Gopło (Methods applied and results obtained in investigations of the thermic conditions of bottom deposits in Lakę Gopło), Prz. Geogr. 45(1): 119-133 (in Polish, English summary).

Grześ M., 1974, Badania nad termiką i zlodzeniem jeziora Gopło (Investigations of the thermic regime and of ice formation at lake Gopło), Dok. Geogr. IG PAN 3: 5-56 (in Polish, English summary).

Grześ M., 1976, Krótkookresowe zmiany temperatury wód jeziornych i stabilności masy wodnej w świetle punktowych pomiarów na jeziorze Gopło (Short-term temperature changes in lake waters and in stability of the water mass, determined by spot measurements made at Lake Gopło), Prz. Geogr. 48(3): 435-456 (in Polish, English summary).

Grześ M., 1978, Termika osadów dennych w badaniu jezior (Thermics bottom deposits in lake exploration), Pr. Geogr. IGiPZ PAN 130: 7-96 (in Polish, English summary).

Grześ M., Sobota I., 1996, Termika osadów dennych jezior Gościąż i Mielec (Thermal conditions of the bottom deposits of lakes Gościąż and Mielec), Acta Univ. Nicol. Coper. Geogr. 28: 75-88 (in Polish, English summary).

Jańczak J., Maślanka W., 2006, Cases of occurrence of secondary metalimnia in some lakes of the Ełk Lakeland, Limnol. Rev. 6: 123-128.

Janiec B., Turczyński M., 1988, Wiosenno-letnia faza cyklu termicznego najgłębszych jezior Pojezierza ŁęczyńskoWłodawskiego (The spring-summer phase of thermal cycle of the deepest lakes in the Lęczna-Włodawa Lakeland), [in:] Michalczyk Z., Wojciechowski K., Badania hydrograficzne w poznawaniu środowiska (Hydrograph- ic studies in environmental recognition), Wydaw. UMCS, Lublin: 59-70 (in Polish).

Jędrasik J., 1975, Anomalie termiczne pod lodem na Jeziorze Raduńskim Górnym (Thermic anomalies under the ice cover on the Upper Lake Raduńskie), Zesz. Nauk. UGdań. Geogr. 3: 193-200 (in Polish, English summary). Jędrasik J., 1985, Uwarunkowania cykli termicznych w jeziorach (Conditions determining thermal cycles in lakes), Zesz. Nauk. UGdań. Geogr. 14: 45-56 (in Polish, English summary).

Jędrasik J., Lange W., 1972, Przebieg wybranych procesów termicznych w jeziorach chmieleńskich w okresie letniej stratyfikacji termicznej (The course of thermal processes in lakes chmieleńskie during the summer thermal stratification), Zesz. Nauk. UGdań. Geogr. 2: 125-140 (in Polish, English summary).

Kanikowski J., 1997, Rozkład temperatury wód jeziora Zamkowego w Wałczu jako podstawa oceny możliwości wykorzystania energii cieplnej (The temperature distribution in the waters of Lake Zamkowe in Wałcz as a basis for assessing the possibility of using thermal energy) [Dissertation], UGdań., Wydz. BiNoZ, Gdańsk, 105 pp (in Polish).

Kitaev S.P., 1978, Termicheskie klassifikacii ozer mira (Thermal classifications of the world's lakes), Vodnye Resursy 1: 97-103 (in Russian).

Koczorowska J., 1974, Porównanie termiki powierzchniowej dwóch jezior na Pojezierzu Sławskim (Comparison of thermal conditions of surface water on two lakes of Sławskie Lake District), Bad. Fizjogr. Pol. Zach. A 27: 61-69 (in Polish, English summary).

Komar T., 1978, Morfometrie Małego i Wielkiego Stawu w Karkonoszach (The morphometry of Mały Staw and Wielki Staw in the Karkonosze Mountains), Acta Univ. Wratisl. Pr. Inst. Geogr. A 2: 75-113 (in Polish, English summary).

Kondracki J., 1952, Obserwacje nad termiką jeziora Niegocin na stacji naukowej Polskiego Towarzystwa Geograficznego w Giżycku (1949-1951) (Observations on thermal conditions of the lake Niegocin), Warszawa, Prz. Geogr. 24(3): 49-71 (in Polish, English summary).

Kowalska A., 1972, Termika jezior północnej Polski (Thermal conditions in the lakes of Northern Poland), Czas. Geogr. 43(4): 371-385 (in Polish, English summary).

Koźmiński Z., Wiszniewski J., 1935, Über die Vorfrühlingthermik der Wigry-Seen (The early spring themperature in Lake Wigry), Arch. Hydrobiol. 28: 198-235 (in German).

Kubiak J., 2003, Największe dimiktyczne jeziora Pomorza Zachodniego. Poziom trofii, podatność na degradację oraz warunki siedliskowe ichtiofauny (The largest dimictic lakes of Western Pomerania. Trophic status, susceptibility to degradation, and ichthyofauna habitat conditions), Rozpr. AR Szczec. 214, Szczecin, 96 pp (in Polish, English summary).

Kubiak J., Oszkinis D., Cabaj A., 2007, Thermal and oxygen conditions in selected lakes of Ińskie Lake District in 
2006 and 2007, [in:] Kubiak J., Bajkiewicz-Grabowska E. (eds), Antropogenic and natural transformations of lakes. Vol. 1, Agricultural University of Szczecin, Polish Limnological Society, Szczecin: 62-64.

Kubiak J., Tórz A., 2005, Water mass dynamics in the largest stratified lakes of Western Pomerania in relation to their trophic status, Sosnowiec, Limnol. Rev. 5: 129-136.

Kubiak J., Tórz A., 2006, Thermal regime of the biggest dimictic lakes of Western Pomerania region, Poznań, Limnol. Rev. 6: 155-162.

Łajczak A., 1982, Wahania temperatury przypowierzchniowej warstwy wody w jeziorach tatrzańskich o różnej ekspozycji (Fluctuation of temperature of the surface water layer in the Tatra lakes of various exposure), Czas. Geogr. 53(1): 29-44 (in Polish, English summary).

Lampert W., Sommer U., 1996, Ekologia wód śródlądowych (Ecology of inland waters), PWN, Warszawa, 290 pp (in Polish).

Lange W., 1975, Z badań nad termiką i bilansem cieplnym jezior (na przykładzie Jeziora Górnego Raduńskiego) (From studies on the thermic conditions and heat balance of the lakes), Zesz. Nauk. UGdań. Geogr. 3: 81-97 (in Polish, English summary).

Lange W., 1978, Warunki akumulacji ciepła w jeziorach Pojezierza Kaszubskiego (Conditions of heat accumulation in the lakes of the Cassubian Lake District), Zesz. Nauk. UGdań. Geogr. 8: 89-108 (in Polish, English summary).

Lange W., 1985a, Ustroje termiczne jezior Pojezierza Kaszubskiego (Thermical regimes of Cassubian Lake District lakes), Zesz. Nauk. UGdań. Geogr. 13: 57-77 (in Polish, English summary).

Lange W., 1985b, Jeziora jako terytorialne systemy przyrodnicze (Lakes as natural territorial systems), Zesz. Nauk. UGdań. Geogr. 14: 17-30 (in Polish, English summary).

Lange W., 1986, Fizyczno-limnologiczne uwarunkowania tolerancji systemów jeziornych (Physico-limnologic conditioning of the Pomeranian lake systems tolerance), Zesz. Nauk. UGdań. Rozpr. Monogr. 79, Gdańsk, 177 pp (in Polish, English summary).

Lange W., 1993, Jeziora jako obiekty badań geograficznych (Lakes as the objects of geographical studies) [in:] Lange W. (ed.), Metody badań fizycznolimnologicznych (Methods of the physico-limnological studies), Wydaw. UG, Gdańsk: 7-19 (in Polish).

Lange W., Faraś-Ostrowska B., 1993, Fizyczne właściwości wód jeziornych (Physical properties of lake waters), [in:] Lange W. (ed.), Metody badań fizycznolimnologicznych (Methods of the physico-limnological studies), Wydaw. UG, Gdańsk: 67-108 (in Polish).

Lange W., Jaś J., Lener B., Lubańska B., Markiewicz W., 1976, Wstepne wyniki badań nad warunkami kształtowania się ustroju termicznego jezior Doliny Pięciu Stawów Polskich (Preliminary results from studiem of the formation of the thermic regime of the lakes of Dolina Pięciu Stawów Polskich), Zesz. Nauk. UGdań. Geogr. 5: 187-199 (in Polish, English summary).
Lange W., Maślanka W., 1997, Fizycznolimnologiczne warunki eutrofizacji jezior zlewni Górnej Raduni (Physico-limnological conditions of lakes eutrophication in upper Radunia drainage-basin), Rocz. Fizycznogeogr. 2: 45-57 (in Polish, English summary).

Lange W., Maślanka W., Nowiński K., 2000, Odrębność i zróżnicowanie fizycznolimnologiczne jezior Tatr Polskich (Physicolimnological separateness and diversification of lakes in the Polish Tatra Mountains), [in:] Czochański J.T., Borowiak D., (eds), Z badań geograficznych w Tatrach Polskich From the geographical investigations in the Polish Tatra Mountains), Wydaw. UG, Gdańsk: 99126 (in Polish, English summary).

Lencewicz S., 1925, Badania jeziorne w Polsce (Lake research in Poland), Prz. Geogr. 5: 1-70 (in Polish, French summary).

Łyczkowska G., 2009, Termika wód Wielkiego Stawu w Karkonoszach (Water temperature of Wielki Staw in the Karkonosze Mountains), Wydaw. Nauk. UAM, Poznań, 136 pp (in Polish).

Marszelewski W., 2001, Jeziora Pojezierza Dobrzyńskiego (Lakes of the Dobrzyń Lakeland), Wydaw. UMK, Torun, $138 \mathrm{pp}$ (in Polish, English summary).

Maślanka W., Barańczuk J., 2007, Termika i dynamika wód (Thermicity and dynamics of water), [in:] Borowiak D. (ed.), Jeziora Kaszubskiego Parku Krajobrazowego (Lakes of the Kashubian Landscape Park), Bad. Limnol. 5: 71-90 (in Polish, English summary).

Maślanka W., Lange W., Borowiak D., 1996, Przyrodnicze uwarunkowania tolerancji wybranych jezior dorzecza Łyny (Natural conditions of tolerance for selected lakes in Łyna drainage-basin), Rocz. Fizycznogeogr. 1: 37-52 (in Polish, English summary).

Maślanka W., Lange W., Nowiński K., 2005, Ustroje termiczne jezior (Thermal regimes of lakes), [in:] Lange W. (ed.), Jeziora Górnej Raduni i jej zlewnia w badaniach z udziałem Stacji Limnologicznej w Borucinie (Lakes of the upper Radunia River and its catchment in research with the participation of the Limnological Station in Borucino), Bad. Limnol. 3: 233-250 (in Polish, English summary).

Maślanka W., Nowiński K., 2006, Diversity of development of summer thermocline layer in Lake Upper Raduńskie, Limnol. Rev. 6: 201-206.

Mientki C., Wiśniewski G., 2001, Characteristics of limnologic seasons in restored Lake Kortowskie in years 19522002, Limnol. Rev. 3: 159-164.

Mikulski Z., Okulanis E., 1974, Ustrój termiczny Jezior Raduńskich (Thermal structure of Raduńskie Lakes), Prz. Geofiz. 19(1): 31-53 (in Polish, English summary).

Nawrocka E., 1986, Temperatura wód powierzchniowych (Temperature of surface waters), [in:] Stachy J. (ed.), Atlas Hydrologiczny Polski. T. II(2) (Hydrological Atlas of Poland. Vol. II(2)), Wydaw. Geol., Warszawa: 588-594 (in Polish). 
Nguyen Van T., 1972, Studia nad chemizmem wód jezior o różnym stopniu troficznym (Studies on the water chemistry of lakes of varying trophic state) [Dissertation], AR Szczec., Szczecin, 76 pp (in Polish).

Nowak B., Grześkowiak A., 2010, Czy rejestracja elektroniczna może zastąpić obserwatorów w pomiarach na jeziorach? (Is electronic registration can replace the observer in measuring the lakes?), [in:] Magnuszewski A. (ed.), Hydrologia w ochronie i kształtowaniu środowiska. T. 2 (Hydrology in the protection and shaping of the environment. Vol. 2), Monogr. PAN Kom. Inż. Środ. 69: 361-369 (in Polish).

Nowiński K., Lange W., Maślanka W., 2005, Conditions of light transmission in water of chosen lakes of Kashubian Lakeland, Limnol. Rev. 5: 183-194.

Okrągła A., 1977, Stosunki termiczne warstwy czynnej bradymiktycznego jeziora Zamkowisko Duże (Thermic relations of the active layer of the bradymictic Lake Zamkowisko Duże, Zesz. Nauk. UGdań. Geogr. 8: 151-164 (in Polish, English summary).

Okulanis E., 1976, Intensywność mieszania się i wymiana wód w zespole Jezior Raduńsko-Ostrzyckich (The rate of water mixing and exchange in the lakes of the Raduńsko-Ostrzyckie lake system), Zesz. Nauk. UGdań. Geogr. 5: 57-71 (in Polish, English summary).

Okulanis E., 1977, Wpływ alimentacji Jezior Radunskich na ich reżim termiczno-lodowy (Effect of the alimentation of Raduńskie Lakes on their thermic and ice regime), Zesz. Nauk. UGdań. Geogr. 8: 109-131 (in Polish, English summary).

Okulanis E., 1981, Studium limnologiczne Jezior RaduńskoOstrzyckich (Limnological study of the lakes of the Raduńsko-Ostrzyckie lake system), GTN-Ossolineum, Gdańsk, 108 pp (in Polish).

Olszewski P., 1959, Stopnie nasilenia wpływu wiatru na jeziora (Graduation in the intensity of the wind effects on lakes), Zesz. Nauk. WSR Olszt. 4: 111-132 (in Polish, English summary).

Olszewski P., Tadajewski A., Lossow K., Więcławski F., 1978, Wstępna charakterystyka limnologiczna niektórych jezior Pojezierza Mazurskiego. Część II (Preliminary limnological characterization of some lakes in the Masurian Lake District. Part II), Zesz. Nauk. ART Olszt. 7: 3-81 (in Polish, English summary).

Onoszko J., 1979, Zastosowanie metody termowizyjnej do oceny powierzchniowego rozkładu temperatury wody na przykładzie Jeziora Żarnowieckiego (The application of a thermovisional method to assess the surface distribution of water temperature exemplified by Lake Żarnowieckie), Stud. Mat. Oceanol. 26: 327-346 (in Polish).

Paschalski J., 1959, Tachymiksja jeziora Dargin (Lake Dargin: A study of tachymixis), Zesz. Nauk. WSR Olszt. 9: 253-291 (in Polish, English summary).

Paschalski J., 1960, Epilimnion Jeziora Mikołajskiego latem 1959 r. (Epilimnion of Lake Mikołajki in summer 1959), Ekol. Pol. B 6 (2): 131-138 (in Polish, English summary).
Pasławski Z., 1993, Badania w dziedzinie limnologii fizycznej w Polsce (Research in the field of physical limnology in Poland), [in:] Dynowska I. (ed.), Przemiany stosunków wodnych w Polsce w wyniku procesów naturalnych i antropogenicznych (Transformations of water conditions in Poland as a result of natural and anthropogenic processes), Wydaw. UJ, Kraków: 56-69 (in Polish).

Patalas K., 1960a, Mieszanie wody jako czynnik określający intensywność krążenia materii w różnych morfologicznie jeziorach okolic Węgorzewa (Mixing of water as a factor determining the intensity of matter flow in morphologically different lakes near Węgorzewo), Rocz. Nauk Rol. B 77(1): 223-242 (in Polish, English summary).

Patalas K., 1960b, Stosunki termiczne i tlenowe oraz przezroczystość wody w 44 jeziorach okolic Węgorzewa (Thermal and oxygen conditions and transparency of water in 44 lakes of Węgorzewo District), Rocz. Nauk Rol. B 77(1): 105-222 (in Polish, English summary).

Pietrucień C., Skowron R., 1983, Anomalie uwarstwienia termicznego wód jezior na przedpolu lodowca Aavatsmarka (Anomalies in the thermal stratification of the waters of the lakes in the forefild of Aavatsmark glacier), X Symp. Polarne: Polskie Badania Polarne 1970-1982, Toruń: 224-238 (in Polish).

Radwan S, Kowalczyk Cz., 1979, Chemizm trzech odmiennych troficznie jezior Pojezierza Łęczyńsko-Włodawskiego (Chemistry of three trophically different lakes at the Łęczna-Włodawa Lakeland), Ann. UMCS C 34: 229-260 (in Polish).

Radwan S., Kowalczyk Cz., Podgórski W., Fall J., 1973, Materiały do hydrochemii Pojezierza Łęczyńsko-Włodawskiego. Część III. Właściwości fizyczne i chemiczne (Materials on hydrochemistry of the Łęczna-Włodawa Lakeland. Part III. Physical and chemical properties), Ann. UMCS C 28: 97-116 (in Polish).

Rösler A., 1986, Termika Jeziora Sławskiego (Thermal characteristics of Lake Sława), Zielona Góra, Rocz. Lubuski 14: 271-293 (in Polish).

Rösler A., 2001, Thermal conditions and resources of Lake Sława, Limnol. Rev. 1: 241-249.

Skowron R., 1980, Letnio-jesienna stratyfikacja termiczna wody w jeziorze Gopło (The summer-autumn thermal stratification of water in the Lake Gopło), Acta Univ. Nicol. Coper. Geogr. 15: 29-48 (in Polish, English summary).

Skowron R., 1982, Termiczne rozwarstwienie wody w jeziorze Gopło w sezonie letnim w latach 1973-1978 (The thermal stratification of water in Lake Gopło in the summers of 1973-1978), Acta Univ. Nicol. Coper. Geogr. 17: 39-52 (in Polish, English summary).

Skowron R., 1990, Struktura termiczna wody w okresie letniej stagnacji na przykładzie wybranych jezior z Pojezierza Gnieźnieńskiego i Kujawskiego (Water thermal structure during the summer stagnation - A case study on selected lasek of the Gniezno and Kuyavian Lake Districts), Acta Univ. Nicol. Coper. Geogr. 22: 45-83 (in Polish, English summary). 
Skowron R., 1995, Dynamika temperatury wody i zasobów ciepła w meromiktycznym jeziorze strefy polarnej (NW Spitsbergen) w okresie lata polarnego (Dynamics of water temperature and heat resources in the polar zone meromictic lake (NW Spitsbergen) during the polar summer), XXII Symp. Polarne: Jedność środowiska przyrodniczego Arktyki i Antarktyki, 27-28 October 1995, Zamek Książ (Poland): 69-83 (in Polish).

Skowron R., 1997a, Czasowo-przestrzenne zróżnicowanie temperatury wody powierzchniowej w jeziorach północnej Polski (Time-spatial variation of surface water temperature in the lakes of northern Poland) [Dissertation], UMK, Wydz. BiNoZ, Toruń, 105 pp (in Polish).

Skowron R., 1997b, Tendencje zmian temperatury wody powierzchniowej i zjawisk lodowych w jeziorach na obszarach pojeziernych w Polsce (Tendencies of changes in the surface water temperature and ice phenomena in the lakes of lakeland areas in Poland), [in:] Choiński A. (ed.), Wpływ antropopresji na jeziora (Influence of anthropopressure on lakes), Wydaw. Homini, Poznań-Bydgoszcz: 143-151 (in Polish).

Skowron R., 1999a, Termiczna sezonowość wody powierzchniowej w jeziorach polskich - jej fluktuacje i tendencje (Thermal seasonality of surface water in Polish lakes - its fluctuations and tendencies), [in:] Choiński A., Jańczak J. (eds), Naturalne i antropogeniczne przemiany jezior (Natural and anthropogenic transformations of lakes), Wydaw. IMiGW, Warszawa: 231-243 (in Polish).

Skowron R., 1999b, Letnia stratyfikacja termiczna wody w jeziorze Hańcza (Thermal stratification of water in Lake Hańcza in summer), Acta Univ. Nicol. Coper. Geogr. 29: 247-256 (in Polish, English summary).

Skowron R., 1999c, Zmiany temperatury wody i zasobów ciepła w przebiegu dobowym na przykładzie epitermicznego jeziora Gopło (Dynamics of water temperature and 24-hour heat reserves on the example of epithermic Lake Gopło), Acta Univ. Nicol. Coper. Geogr. 31: 289-306 (in Polish, English summary).

Skowron R., 2000, O dobowej zmienności temperatury wody i zasobów ciepła w jeziorach (Diurnal changeability of temperature and heat content in lakes), [in:] Lossow K., Gawrońska H. (eds), Naturalne i antropogeniczne przemiany jezior (Natural and anthropogenic transformations of lakes), Wydaw. UWM, Olsztyn: 45-58 (in Polish, English summary).

Skowron R., 2001, Surface water thermal seasons in Polish lakes, their distribution and spatial differentation, Limnol. Rev. 1: 251-263,

Skowron R., 2006, Differences in thermal and ice regimes formation in lakes Gopło and Bachotek, Limnol. Rev. 6: 255-262.

Skowron R., 2007a, Roczny cykl temperatury wody powierzchniowej w jeziorach na Niżu Polskim i jego zmienność (Annual cycle of surface water temperature in the lakes in the Polish Lowland and its changeability), [in:] Michalczyk Z. (ed.), Obieg wody w środowisku natural- nym i przekształconym (Water circulation in natural and transformed environment), Badania hydrograficzne w poznawaniu środowiska 8: 452-461 (in Polish, English summary).

Skowron R., 2007b, The thermocline layer in the thermal water structure of selected polish lakes, [in:] Kubiak J., Bajkiewicz-Grabowska E. (eds), Antropogenic and natural transformations of lakes. Vol. 1, Agricultural University of Szczecin, Polish Limnological Society, Szczecin: 115-118.

Skowron R., 2007c, The thermocline layer in the thermal water structure of selected Polish lakes, Limnol. Rev. 7(3): $161-169$.

Skowron R., 2008a, Thermal conditions of water in lakes during winter stagnation - Selected problems, [in:] Bajkiewicz-Grabowska E., Borowiak D. (eds), Antropogenic and natural transformations of lakes. Vol. 2, Wydaw. KLUG-PTLim, Gdańsk: 187-190.

Skowron R., 2008b, Water thermal conditions during winter stagnation in the selected lakes in Poland, Limnol. Rev. 8(3): 119-128.

Skowron R., 2009a, Criteria of thermal classifications of lakes, Bull. Geogr. Phys. Geogr. 2: 93-108.

Skowron R., 2009b, Kształtowanie się temperatury wody w okresie letniej stagnacji w najgłębszych jeziorach niżowych Polski (Water temperature in the deepest lakes of the Polish Lowland during summer stagnation), [in:] Bogdanowicz R., Fac-Beneda J. (eds), Zasoby i ochrona wód. Obieg wody i materii w zlewniach rzecznych Water resources and water protection. Water and matter cycling in river basins), Wydaw. FRUG, Gdańsk: 81-95 (in Polish, English summary).

Skowron R., 2009c, Extreme thermal phenomena of surface water in the lakes of Northern Poland, Limnol. Rev. 9 (2-3): 97-109.

Skowron R., 2009d, Temperatura wody w jeziorach w Polsce Północnej jako wskaźnik zmian klimatu (Water temperature of lakes in Northern Poland as an index of climate change), [in:] Jankowski A.T., Absalon D., Machowski R., Ruman M. (eds), Przeobrażenia stosunków wodnych w warunkach zmieniającego się środowiska (Transformation of the water relationships in changing environmental conditions), Wydaw. UŚ, Sosnowiec: 255-268 (in Polish, English summary).

Skowron R., 2010, Typologia termiczna jezior na Pojezierzu Brodnickim (Thermal typology of lakes in the Brodnica Lake District), [in:] Choiński A. (ed.), Przemiany jezior i zbiorników wodnych (Transformations of lakes and reservoirs), Stud. Pr. Geogr. Geol. 10, Bogucki Wydaw. Nauk., Poznań: 109-120 (in Polish, English summary).

Skowron R., 2011a, Zróżnicowanie i zmienność wybranych elementów reżimu termicznego w jeziorach na Niżu Polskim (The differentiation and the changeability of chosen elements of the thermal regime of water in lakes on Polish Lowland), Wydaw. UMK, Toruń, 345 pp (in Polish, English summary). 
Skowron R., 2011b, Kształtowanie się temperatury wody w okresie wiosennego nagrzewania $\mathrm{w}$ wybranych jeziorach $w$ Polsce (Course of water temperature in the spring warming season in the selected Polish lakes), [in:] Marszelewski W. (ed.), Anthropogenic and natural transformations of lakes. Vol. 5, Wydaw. UMK-PTLim, Torun: 145-155 (in Polish, English summary).

Skowron R., 2012, Spring warming period of Polish lake waters in a yearly thermal cycle, Limnol. Rev. 12(3): 147157.

Skowron R., Piasecki A., 2014, Water temperature and its diversity in the deepest lakes of the Tuchola Forest and the Kashubian and Brodnickie Lakelands, Bull. Geogr. Phys. Geogr. 7: 103-117.

Sobolewski W., Borowiak D., Borowiak M., Skowron R., 2014, Baza danych jezior Polski i jej wykorzystanie w badaniach limnologicznych (Database of Polish lakes and its use in limnological studies), Wydaw. "Picador" - UMCS, Lublin, 198 pp (in Polish).

Sobota I., Nowak M., 2011, Charakterystyka warunków batymetrycznych i termicznych kompleksu jezior na przedpolu lodowca Aavatsmarka, Svalbard (Bathymetric and thermal conditions of lakes located in the forefield of Aavatsmark Glacier, Svalbard), Probl. Klim. Polar. 21: 187-196 (in Polish, English summary).

Starmach K., Wróbel S., Pasternak K., 1976, Hydrobiologia (Hydrobiology), PWN, Warszawa, 621 pp (in Polish).

Świdzińska L., 1939, O ciepłocie wody płytkich jezior Polesia w latach 1929-1935 (On the warmth of the shallow lakes of Polesye in the years 1929-1935), Wiad. Sł. Hydrogr. 2(1): 35-43 (in Polish).

Szaflarski J., 1932, Z badań nad termiką jezior tatrzańskich (On temperature of the Tatra lakes), Prz. Geogr. 12: 181184 (in Polish).
Szaflarski J., 1950, Z zagadnień zimowej termiki jezior tatrzańskich (From issues of winter temperature of the Tatra lakes), Prz. Geogr. 22: 281-289 (in Polish).

Szumiec M., 1984, Termika stawów karpiowych (Thermal properties of carp ponds), PWN, Warszawa, 136 pp (in Polish).

Trojanowski J., Bruski J., 2002, Thermal and oxygenic characteristic of Rzuno Lake (Kaszuby Lakeland), Arch. Ochr. Środ. 28(1): 81-95.

Trojanowski J., Parzych A., 2004, Warunki termiczno-tlenowe jeziora Ińsko (Thermal and oxygen conditions of Lake Ińsko), Arch. Ochr. Środ. 30(3): 147-160 (in Polish, English summary).

Turczyński M., 1995, Termika jezior Łęczyńsko-Włodawskich (Thermal properties of the Łęczna-Włodawa lakes) [Dissertation], UMCS, Wydz. BiNoZ, Lublin, 84 pp (in Polish).

Turczyński M., 1998, Termika najgłębszych jezior łęczyńsko-włodawskich (Thermal properties of the deepest lakes of the Łęczna-Włodawa region), [in:] Haramisuk M., Michalczyk Z., Turczyński M. (eds), Jeziora Łęczyńsko-Włodawskie. Monografia Przyrodnicza (Lakes of the Łęczna-Włodawa region. Natural monograph), Wydaw. UMCS-PIOŚ, Lublin: 105-111 (in Polish).

Welch P.S., 1948, Limnological methods, Blakiston Co., Toronto, $381 \mathrm{pp}$.

Wilgat T., 1953, Jeziora Łęczyńsko-Włodawskie (ŁęcznaWłodawa Lakes), Ann. UMCS B 8(3): 36-121 (in Polish).

Wiszniewski J., 1954, Uwagi w sprawie typologii jezior polskich (Remarks on the typological classification of lakes in Poland), Pol. Arch. Hydrobiol. 1: 11-23 (in Polish, French summary). 